\title{
Model of Stress-testing of Banks' Liquidity Risk in Ukraine
}

\section{Olena Krykliy}

Ph.D., Associate Professor, Department of Finance, Banking and Insurance, Sumy State University, Ukraine

\section{Iryna Luchko}

Master's degree student, Department of Finance, Banking and Insurance, Sumy State University, Ukraine

\begin{abstract}
The global financial crisis has shown how important is the role of liquidity risk in ensuring the stability of the banking system, and revealed a number of deficiencies in its regulation, both at the level of individual banks and at the level of banking regulation and supervision. It is necessary to develop new instruments and improve of existing instruments for protection the banking system from the negative effects of liquidity risk. These tools necessarily include stress testing of liquidity risk. In order to increase the efficiency of liquidity risk management of Ukrainian banks at micro and macro levels, the authors propose to apply stress testing of liquidity of assets. The stress-testing model is based on three phases: the formation of a liquidity deficit in the balance as a primary effect of the shocks; bank reactions to shocks; feedback effects from shocks. According to the model, the liquidity buffer is calculated and the banks have sufficient liquid assets to cover the liquidity deficit.

The model was tested on a group of Ukrainian banks with a state stake (JSB "Ukrgasbank", JSC "Oschadbank", JSC "Ukreximbank" and PJSC "PrivatBank"), the impact of which on the banking system of Ukraine is the most significant, based on data from 2012 to 2016. According to the results of the study, it was determined that with a sufficient amount of assets liquidity buffers in state-owned banks, their quality remains rather low, the share of secondary reserves in banks is critically low. For the crucial role of this segment in the Ukrainian banking system, it is necessary to improve the liquidity management system of this group of banks, including, in order to minimize the systemic liquidity risk.
\end{abstract}

This test may use prudential oversight bodies as an appropriate alternative to available liquidity risk assessment tools (primarily established by the NBU for liquidity ratios) at both micro and macro levels of liquidity regulation.

Keywords: liquidity, liquidity risk, liquidity stress testing, Banks’ Liquidity Buffers. JEL Classification: G12, G19, G21.

(C) The Authors, 2018. This article is published with open access at ARMG Publishing.

\section{Introduction}

The liquidity risk at the present stage of functioning of financial systems is an important subject of banking regulation and supervision, as the global financial crisis of 2008-2009 has shown how operating conditions of banks' operations can change rapidly, causing significant liquidity disruptions. It also proved that the probability of systemic liquidity squeeze banks was higher than the sum of liquidity risks associated with each individual bank.

This topic is also important for the banking system of Ukraine, as banks are forced to work in the uncertain environment of the operating environment, reduce capital adequacy, instability of the resource base and increase the share of problem loans in the loan portfolio, which negatively affects the level of liquidity and increases the risk of liquidity .

A significant increase in liquidity risk led to the reform of the banking regulation and supervision system in this area. The Basel Committee on Banking Supervision has initiated two new liquidity standards in global banking regulation, the Liquidity Ratio (LCR) and the Clean Stable Financing Factor (NSFR), designed to increase banks' liquidity buffers and financial sustainability, respectively [1]. The European Systemic Risk Board recommended that national oversight bodies strengthen their supervision of liquidity and funding risks (ESRB 2012) [4].

The National Bank of Ukraine in 2015 developed a Comprehensive Program for the Development of the Financial Sector of Ukraine until 2020, which provides for the introduction of LCR and NSFR liquidity ratios. 
In 2017, a Plan of Measures for the Implementation of EU norms (CRD IV / CRR) and a Plan of Measures for the Improvement of Banking Supervision, envisaging specific mechanisms for the implementation of LCR and NSFR liquidity ratios in the Ukrainian banking system, were adopted. Starting from June 1, 2018, the LCR liquidity ratio was introduced in the test mode. From December 1, 2018, LCRs are required to be met by banks as one of the economic standards. The use of this indicator in micro-prudential supervision will increase banks' resilience to short-term liquidity shocks and will facilitate the approximation of banking regulation standards in Ukraine to European ones.

In addition to the introduction of new tools for micro-prudential supervision, the growth of liquidity risks leads to the need to improve the methodology for measuring both the systemic liquidity risk (macro level) and the magnitude of the impact of individual banks on the scale of the formation and implementation of these risks, which will improve the mechanisms for their regulation. Currently, the key tool for measuring liquidity risks is stress testing as an assessment of the potential impact on the liquidity of a number of specified changes in risk factors that are consistent with exceptional but probable events.

Objectives. The purpose of this research is approbation of model stress testing of liquidity on the data of banks of Ukraine with state participation, which is based on the recalculation of liquidity buffers after exposure to several types of shocks. The approach combines the risks of market liquidity and the risk of financing the liquidity of banks, and the feedback between them leads to a secondary impact of market imbalances on banks.

\section{Literature review}

The research is important but rather new for the banking system. This element of risk management and banking regulation is stress testing, which attracts the attention of many domestic scientists. Theoretical and methodological aspects of stress-testing of banks are investigated in the works of P. Zhytnyi (2008) [34]; S. Naumenkova and S. Mishchenko (2008) [26]; I. Ivasiv (2011) [17, 18]; N. Mazun (2010) [25]; A. Maksymova (2012) [23]; V. Vovk (2013) [32]; B. Kyshakevych (2011) [21]; L. Danilova and V. Savochka (2014) [11]; S. Manzhos (2014) [24]; Yu. Diuba, A. Murina, (2015) [13]; B.Kyshakevych and O. Yuzvyak (2015) [22]; G. Bortnikov and O. Liubich (2016) [8] and others. Despite a strong methodological basis, there is virtually no research on stress testing of liquidity risk.

In the work of Yu.Rebryk and M. Rebryk (2013), a scientific and methodical approach to scenario stress testing of liquidity of the bank is proposed, which provides an assessment of the state of all components of liquidity (individual components of liquidity, liquidity buffer, purchased liquidity and owner's resources) taking into account the influence of external shocks The obtained results provide an opportunity to define and form the necessary liquidity buffer, which will help the bank to remain financially sustainable even in the context of a systemic crisis [27].

I. Ivasiv, O.Fuksman (2014) developed an approach to liquidity stress testing standard values and internal liquidity limits that can be used as warning signals to prevent abuse external requirements of the regulator, according to a certain factor change rate [17].

E. Travkyna (2015) in [29] determines the important role of stress testing in monitoring the risk of liquidity. This indicates that stress testing liquidity risk involves the use macro model and sensitivity analysis of secondtier banks to liquidity shocks.

A.Kuznetsov and A.Pyitkin (2015) substantiate the feasibility of both historical and hypothetical stress scenarios liquidity. However, they indicated that hypothetical scenario in unstable situations can provide a strategic advantage to banks. Scenarios liquidity stress test should cover all areas of business where the possible outflow of liquidity in particular, have to take into account behavioral patterns of depositors; separately predict the outflow of funds from current and card accounts of individuals, funds of legal entities for all the products they use; anticipate the probability of non-expansion of deposits; take into account only real sources of funding to cover liquidity outflows [20].

Bearing in mind the importance of the problem of ensuring sufficient liquidity, the Basel Committee on Banking Supervision has developed recommendations for stress testing of liquidity [2].

In this document stress tests of liquidity of macro and micro level. Macro stress tests are part of the macroprudential toolkit that authorities may use to detect system-wide liquidity risks. Macro stress tests can be conducted either bottom-up or top-down. Bottom-up stress tests are conducted by banks, based on their own assumptions or on common scenarios designed by the central bank or supervisor for a horizontal review. The 
bodies of banking regulation, usually based on in-house models and common assumptions across firms and supervisory and/or publicly available data, conduct top-down stress tests. In practice, most bodies of banking regulation conduct both top-down, bottom-up stress tests, as these are complementary, and allow for valuable crosschecks. At the micro level, large banks build their own bespoke liquidity risk stress tests; small and medium-sized banks use off-the-shelf models. The results of stress testing including are used for the definition and composition of liquidity buffers available to absorb liquidity stress. Modern approach goes towards asset liquidity (rather than liability liquidity) taking into account that in the crisis several asset classes turned out to be less liquid than expected.

In paper E. Wong and C. Hui (2009) develop a framework for stress-testing banks' liquidity risk, where liquidity and default risks can stem from market risk arising from asset price shocks. The framework quantifies liquidity risk by estimating the expected cash shortage time and the expected default time of banks. The stress-testing framework explicitly captures the link between default risk and deposit outflows, not only are the interaction of the risks incorporated but also their contagious effects [33].

D. Aikman et al. (2009) provide a tractable stress-testing approach to modeling funding liquidity risks, solvency risk, and externalities through spillover effects due to interbank exposures. In their framework, rules of thumb are used to impose funding constraints once banks' balance sheets deteriorate beyond certain exogenous thresholds [5]. In paper C. Gauthier, M. Souissi, \& X. Liuc (2014) expanded the model Aikman et al. (2009) and model E. ong and C. Hui (2009). They provided analytical underpinnings for the link between solvency risk, market liquidity risk, and funding liquidity risk, rather than relying on exogenous thresholds [15].

The results of the study of stress testing of banks 'liquidity showed that the focus was on assessing the adequacy of banks' liquidity reserves (so-called liquidity buffers) to cover significant outflows in the short-term period. This is because during the crisis periods, the banks' liquidity deficit is covered by primary and secondary liquidity reserves, as the money market acquisitions become inaccessible.

Based on this much of the research is devoted to the study of liquidity buffer, the factors that determine its size and sufficiency to cover liquidity shortages.

R. Cifuentes, Hyun Song Shin \& Gianluigi Ferrucci (2005) suggest that liquidity buffer requirements may be more effective than capital buffers in forestalling systemic crises. During periods of major financial distress, even a large capital buffer may be insufficient to prevent contagion as assets can only be sold at a discount. Requirements to maintain a stock of liquid assets can internalise some of the negative externalities that are generated by the price impact of selling less liquid assets [10].

Chen I-Ju \& Phuong Nguyen Lan (2013) [9] investigated factors that determine of the size of the liquidity buffer in banks. They examined the impact of bank loan-related operations, bank characteristics, macroeconomic fundamentals, and regulatory policy on the bank liquidity buffer. They revealed demand for liquidity is countercyclical, and bank excess liquidity runs counter to the business cycle. The level of bank liquidity buffer increases during a period of crisis.

In order to increase the efficiency of liquidity risk management A.Ushanov (2016) suggested to calculate and maintaine the stress-buffer of liquidity, which may require the bank in critical operating conditions, such as in the case of unpredictable payments on customer deposits [30].

Study M. Sun (2018) focuses on the portfolio allocation and liquidity buffer and how they are affected by the liquidation cost and risk preference. The key result of his research is the employment of framing effect in the classic bank run model and the analysis of determinants of liquidity buffer that a bank should hold in the face of funding liquidity shock. The author identified that liquidity buffer could not be a constant variable which represents the absolutely optimal value of liquidity holding in commercial banks, while the liquidity buffer should be dynamic and adjustable under different economic circumstances. He considers, it is also necessary to study the framing effect of general depositors, especially institutional wholesale lenders, and incorporate the effect into the modeling of bank run and more extensive banking crisis [28].

Currently, the formation of liquidity buffers is given great importance to regulators. Committee of European Banking Supervisors developed guidelines are focused on liquidity buffers. In them it is determined that liquidity risk management in banks should use of a broad range of measures including, among others, stresstest-based liquidity buffers or refinancing limits for shorter and longer periods and contingency planning. The 
document elaborate upon the appropriate size and composition of liquidity buffers to enable credit institutions to withstand a liquidity stress for a period of at least one month without changing their business models [3].

A separate line of research is devoted to the study of the specifics of the of Banks' Liquidity Buffers of different countries.

The results of study C. Delechat, C. Arbelaez, P. Muthoora, S. Vtyurina (2012) [12] reveal that banks' liquidity holdings are comfortably above legal or prudential requirements in Central America, Panama and the Dominican Republic. Using a panel of about 100 commercial banks from the region in 2006-2010, they found that the demand for precautionary liquidity buffers is associated with measures of bank size, profitability, capitalization, and financial development. Important for the Ukrainian banking system is their conclusion that deposit dollarization is also associated with higher liquidity, reinforcing the monetary policy and market development challenges in highly dollarized economies. Improvements in supervision and measures to promote dedollarization, including developing local currency capital markets, would help enhance financial systems' efficiency and promote intermediation in the region.

C. Bonner, I. van Lelyveld \& R. Zymek (2013) [6, 7] based on a sample of 7,000 banks in 30 OECD countries, argue that banks' liquidity buffers are determined by a combination of both bank- and country-specific variables. The results of the study, obtained by authors identified the presence of liquidity regulation substitutes for most of these determinants while complementing the role of size and institutions' disclosure requirements. The complementary nature of disclosure and liquidity requirements provides a strong rationale for considering them jointly in the design of regulation.

N. Gorelaya \& K. Kuznetsova (2017) using bank level data, analyze the impact of different factors on the liquidity buffer as created by commercial banks. The regression results indicated that bank size and the sustainability of bank sources reduce the amounts of liquid assets on the bank's balance sheet. On the other hand, a return on assets and credit risk ratios increase the size of the liquidity buffer because banks increase the loan volume and they are supposed to have a high level of loan losses by trying to invest more resources in liquid assets. No convincing statistical proof was found for the theoretical hypothesis that the influence of the bank ownership, whether state or foreign-owned, or the deposit insurance coverage are significant. They find that macroeconomic conditions (GDP growth, funding rate, and crisis) are also significant for the liquidity statement of Russian banks. The finding suggests that the process of creating the liquidity buffer is procyclical, meaning that banks accumulate liquidity in times of economic recovery and spend it during a crisis period [16].

\section{Methodology and data}

The article is prepared using the theoretical-analytical approach. It contains the analysis of the literature on the theory of liquidity risk of banks and stress testing of liquidity risk.

Based on the approach of Z.Komárková, A. Gershl, L. Komarek (2011) [19], within this study we distinguish between liquidity (of any kind) and liquidity risk. Liquidity is a binary notion, since a bank or market is, or is not, liquid at a particular time point. On the other hand, liquidity risk is defined as the possibility that the bank will become illiquid or market - a variable that is measured over a certain time period. Liquidity risks are heterogeneous in their structure. According to M. Drehmann and K. Nikolaou (2009) [14], the risk of liquidity financing is the risk of a bank's failure to settle its obligations.

The risk of market liquidity arises from the inability of the bank to close the position (to realize the asset) at market price. It is based on the ability of assets to be transformed into cash, with this transformation taking place within the existing market, and its effectiveness (speed and absence of unacceptable losses) is conditioned both by the state of the asset itself and by market conditions at a specific time. Assets can be liquid at a specific time, but at other times the prices for them can be significantly reduced.

In the context of developing a stress testing model, it is important to conclude that the bank's liquidity risk is closely related to the ability to convert assets into cash without unacceptable losses (market liquidity). In addition, since the relationship between market liquidity and liquidity of funding is bilateral, there is potential for the feedback effect, and the liquidity shock for one bank can be spread across the interbank channel and lead to an increase in systemic liquidity risk.

For the research, the model of J. V. Van den End (2008) [31] was used. Its model is based on the repeated counting of liquidity buffers after the impact of several types of shocks, combining market risks of the market 
and financing liquidity of banks, and the feedback between them leads to a secondary impact of market violations on banks. His achievements were developed in the work of Z. Komárková, A. Gershl, L. Komarek (2011) [19] with a number of changes, determined both by the available analytical

data and the specifics of the functioning of banking systems. First, the model of J.V. Van den End (2008) includes a combined approach to stocks and cash flows, whereas in the absence of reporting data in the work of Z. Komárková, A. Gershl, L. Komarek (2011) only the stock of liquid assets. Secondly, the shocks of the first round take into account both the reduced value of assets, on the one hand, and the growth of the amount of loans, on the other (both increase the need for financing), while the model J. V. Van den End (2008) takes into account only the first case. The third group of differences is related to the assumption of the banks' reactions and the trigger for these reactions. Model J. V. Van den End (2008) assumes that banks adopt regulatory measures (sale of securities, issue of additional securities or replacement of certain assets or liabilities by other clauses) if the decline of the liquidity buffer after the first round of effects violates a certain threshold. In the work of Z. Komárková, A. Gershl, L. Komarek (2011), it is assumed that banks react when cash and deposits (or other accounts receivable) of the central bank are exhausted.

Within the framework of this research, the approach was adapted to the specifics of the functioning of Ukrainian banks, in particular, the composition of primary and secondary liquidity buffers was reviewed in accordance with the financial reporting data.

The stress test model is based on three phases: formation of the liquidity deficit in the balance as a primary effect of the shocks; Bank reactions to shocks; feedback effects from shocks.

According to the model, the liquidity buffer is calculated and the banks have sufficient liquid assets to cover the liquidity deficit.

This test may use prudential oversight bodies as an appropriate alternative to existing instruments for assessing liquidity risk (primarily, liquidity ratios set by banking regulation and oversight authorities). The model can be used to quantify the effect of liquidity on individual banks or the banking system as a whole.

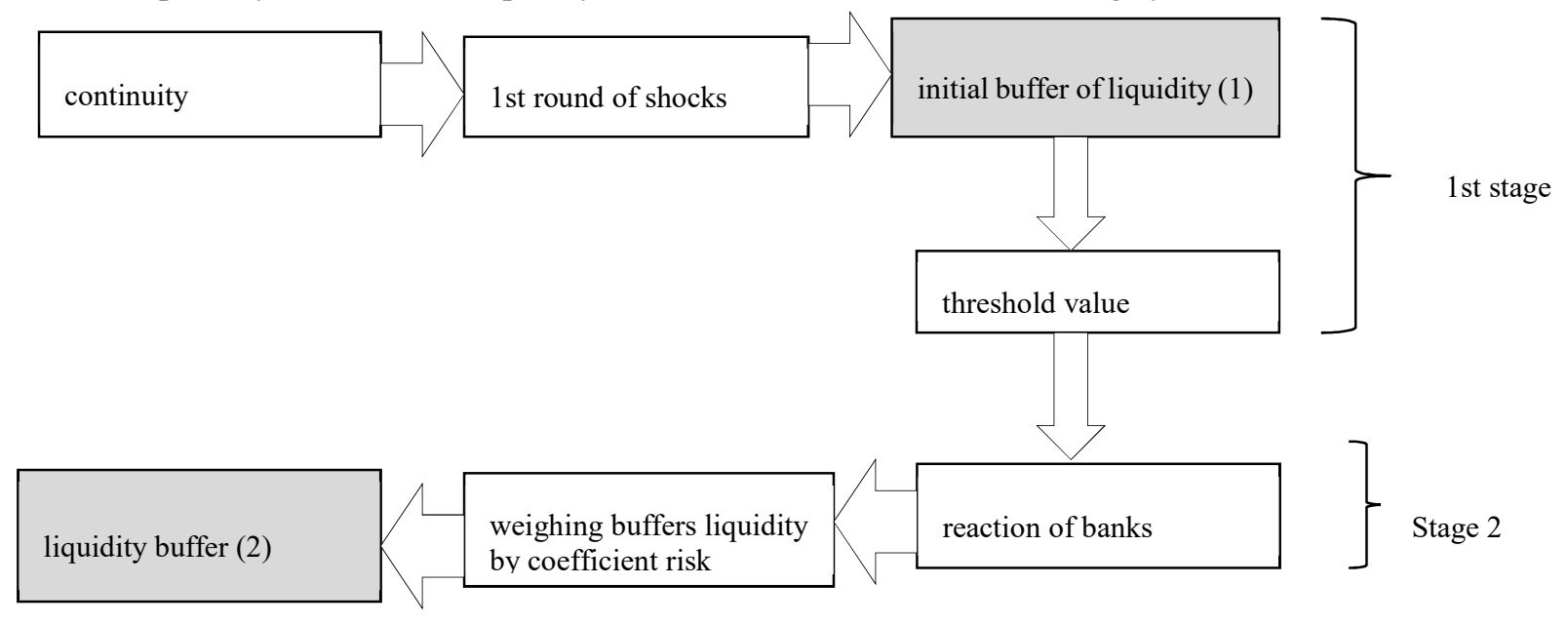

Figure 1. Scheme of stress testing of liquidity of the bank

Figure 1 depicts a basic stress-testing scheme for the proposed approach. The model used in the work involves the sequential realization of three stages.

At the first stage, we calculate the initial liquidity buffer of the bank's assets by the formula (1).

$$
L B_{0}=\sum_{i=1}^{4} L_{B i} \text {, }
$$

where $\mathrm{i}$ - a separate element of the balance, B - separate bank, I - articles consisting of primary and secondary liquidity reserves: (1) cash and cash equivalents, (2) funds of the bank's mandatory reserves in the NBU, (3) funds in other banks, (4) trading securities.

At this stage, it is necessary to check the initial liquidity buffer at the threshold (R) - the indicator of liquidity deficit, calculated by the formula (2): 
$R=L * p+C * c+D * r$,

where $\mathrm{L}$ - loan portfolio of the bank; $\mathrm{p}$ - the growth rate of the loan portfolio; $\mathrm{C}$ - other financial assets; $\mathrm{c}$ share of overdue loans; D - deposits; $r$ - withdrawal rate.

The next step is to compare the size of the liquidity gap (R) with the initial liquidity buffer (LB0) (formula 3): $\frac{L B_{0}}{R} \geq 1$

If this condition is fulfilled, the bank is able to withstand the first round of shocks, its liquidity buffer of assets is sufficient, which allows it to move to the second stage. It needs to weigh the liquidity buffer on the risk factors (formula 4):

$L B_{0}=\sum_{i=1}^{4} L_{B i} * h_{i}$,

where $h_{i}$ risk ratio for the asset group.

Since primary and secondary liquidity reserves are included in asset liquidity buffers, the risk factors will be $0 \%$ and $10 \%$ respectively. Then compare the resulting liquidity buffer (2) with the liquidity deficit (R) indicator by analogy with formula (3). If in this case the condition is fulfilled, this will indicate the high quality and adequacy of the bank's liquidity buffer.

For the study, a group of banks with a state share has been selected, as its influence on the banking system is the most significant (as of 01.07.2017, the share of assets of a group of banks with a state share is $56 \%$ of assets of the banking system). Thus, in view of this, the state of liquidity of assets of JSB "Ukrgasbank", JSC "Oschadbank", JSC "Ukreximbank" and PJSC "PrivatBank" was investigated. JSC "Ukrainian Bank for Reconstruction and Development" and PJSC "Settlement Center" were not included in the stress-testing model, since their share of assets in the banking system is insignificant (less than 1\%). The empirical analysis covers five years (2012-2016) and is based on the annual data presented in Appendix A.

\section{Results}

According to the model of stress-testing in the first stage it is necessary to calculate the initial buffer of liquidity of banks assets by the formula (1). Figure 2 shows the results.

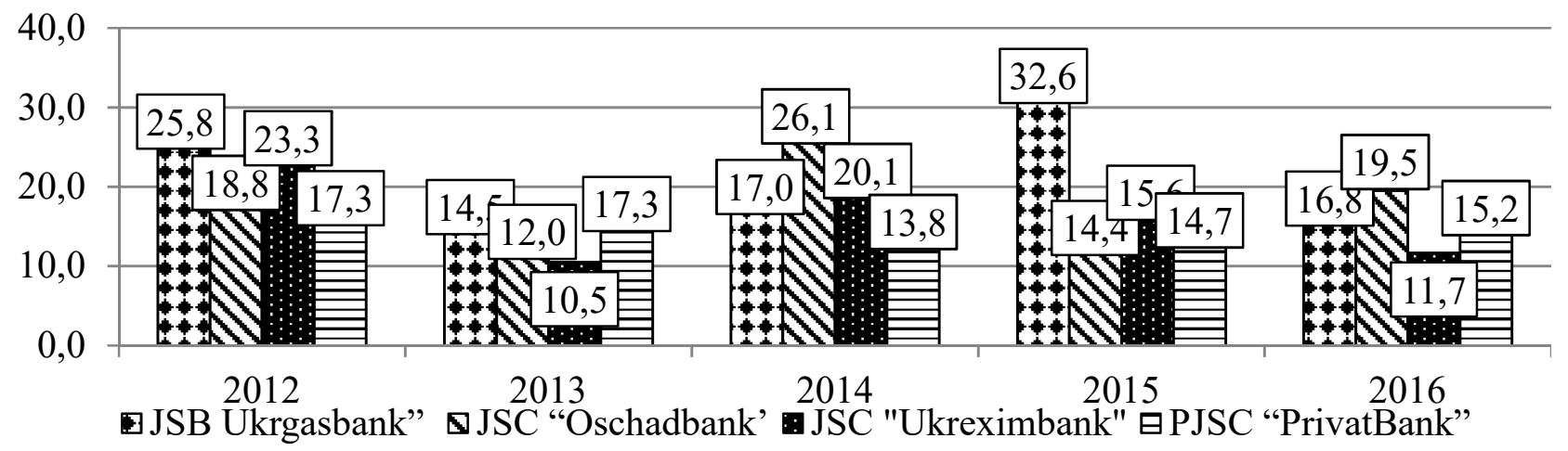

Figure 2. Change in the liquidity buffers of assets of JSB "Ukrgasbank", JSC "Ukreximbank", JSC"Oschadbank", PJSC "PrivatBank" for 2012-2016, \%

During the study period, fluctuations of assets liquidity buffers in each investigated bank were observed. Detailed elements of the buffers of liquidity are given in Table 1.

According to data, we see that in JSB "Ukrgasbank", starting from 2012, there was a decrease in the share of cash and cash equivalents from $12.3 \%$ to $4.62 \%$. The share of funds in other banks increased from $3 \%$ in 2013 to a maximum of $23.1 \%$ in 2015 . At the last date of analysis, the highest value of the liquidity buffer is available in JSC "Oschadbank" - 19.5\%, which is due to an increase in the share of cash and cash equivalents by $5 \mathrm{pp}$. 
Table 1. Components of liquidity buffers JSB "Ukrgasbank", JSC "Ukreximbank", JSC"Oschadbank", PJSC"PrivatBank" for 2012-2016, \%

\begin{tabular}{|c|c|c|c|c|c|}
\hline$\underset{\text { years }}{ }$ Components & $\begin{array}{l}\text { Cash and cash } \\
\text { equivalents, } \%\end{array}$ & $\begin{array}{l}\text { Funds of mandatory reserves } \\
\text { of the bank in nbu, } \%\end{array}$ & $\begin{array}{l}\text { Funds in other } \\
\text { banks, } \%\end{array}$ & $\begin{array}{l}\text { Trading } \\
\text { chains, } \%\end{array}$ & Lb (liquidity buffer) \\
\hline \multicolumn{6}{|c|}{ JSB "Ukrgasbank" } \\
\hline 2012 & 12.31 & 0.17 & 7.68 & 5.66 & 25.83 \\
\hline 2013 & 8.67 & 0.57 & 3.01 & 2.20 & 14.45 \\
\hline 2014 & 9.34 & 0.00 & 3.82 & 3.84 & 17.00 \\
\hline 2015 & 9.55 & 0.00 & 23.10 & 0.00 & 32.65 \\
\hline 2016 & 4.62 & 0.00 & 12.15 & 0.00 & 16.77 \\
\hline \multicolumn{6}{|c|}{ JSC "Oschadbank" } \\
\hline 2012 & 17.91 & 0.10 & 0.77 & 0.00 & 18.79 \\
\hline 2013 & 6.71 & 0.50 & 4.77 & 0.00 & 11.98 \\
\hline 2014 & 20.41 & 5.09 & 0.62 & 0.00 & 26.13 \\
\hline 2015 & 14.25 & 0.00 & 0.13 & 0.00 & 14.38 \\
\hline 2016 & 19.49 & 0.00 & 0.05 & 0.00 & 19.54 \\
\hline \multicolumn{6}{|c|}{ JSC "Ukreximbank" } \\
\hline 2012 & 21.09 & 0.60 & 1.65 & 0.00 & 23.35 \\
\hline 2013 & 7.66 & 0.79 & 2.05 & 0.00 & 10.49 \\
\hline 2014 & 12.00 & 0.00 & 2.59 & 5.46 & 20.05 \\
\hline 2015 & 2.33 & 0.00 & 13.27 & 0.00 & 15.61 \\
\hline 2016 & 4.11 & 0.00 & 7.58 & 0.00 & 11.69 \\
\hline \multicolumn{6}{|c|}{ PJSC"PrivatBank" } \\
\hline 2012 & 15.63 & 0.72 & 0.90 & 0.00 & 17.25 \\
\hline 2013 & 14.99 & 0.73 & 1.63 & 0.00 & 17.35 \\
\hline 2014 & 13.23 & 0.00 & 0.60 & 0.00 & 13.83 \\
\hline 2015 & 13.69 & 0.00 & 0.97 & 0.00 & 14.65 \\
\hline 2016 & 14.17 & 0.00 & 0.99 & 0.00 & 15.16 \\
\hline
\end{tabular}

The lowest value of the liquidity buffer in 2016 was observed in JSC "Ukreximbank" - 11.7\%, which was caused by a reduction in the share of cash and cash equivalents from $21 \%$ to $4.1 \%$.

PJSC"PrivatBank", on average, had the lowest level of liquidity buffer in the group, ranging from the maximum in $2012-17.3 \%$ to the minimum in $2014-13.8 \%$. This bank has the lowest share of funds in other banks in the group, which did not exceed $1 \%$. For the transition to the second stage, it is necessary to calculate the asset liquidity deficit (R) by formula (2) and formula (3) and compare it with the available liquidity buffer in absolute terms. Table 2 shows the corresponding calculations.

Table 2. Calculation of the first round of shocks for 2012-2016

\begin{tabular}{|c|c|c|c|c|c|}
\hline \multicolumn{6}{|l|}{ JSB "Ukrgasbank" } \\
\hline & 2012 & 2013 & 2014 & 2015 & 2016 \\
\hline LB0, thousand grn & 5423299 & 3439026 & 3573945 & 13567049 & 9004060 \\
\hline $\mathrm{R}$, thousand grn & 2228061 & 2453067 & 3280169 & 3804789 & 4959517 \\
\hline LB0/R & 2.43 & 1.40 & 1.09 & 3.57 & 1.82 \\
\hline \multicolumn{6}{|c|}{ JSC "Oschadbank" } \\
\hline & 2012 & 2013 & 2014 & 2015 & 2016 \\
\hline LB0, thousand grn & 7651362 & 5892094 & 6854115 & 17371841 & 13963579 \\
\hline $\mathrm{R}$, тис.грн & 5901483 & 6097741 & 9529601 & 12567899 & 14556869 \\
\hline LB0/R & 1.30 & 0.97 & 0.72 & 1.38 & 0.96 \\
\hline \multicolumn{6}{|c|}{ JSC "Ukreximbank" } \\
\hline & 2012 & 2013 & 2014 & 2015 & 2016 \\
\hline LB0, thousand grn & 13552846 & 11989836 & 16383716 & 29939741 & 28520448 \\
\hline $\mathrm{R}$, thousand grn & 7011408 & 6335656 & 6882708 & 7757726 & 7483182 \\
\hline LB0/R & 1.93 & 1.89 & 2.38 & 3.86 & 3.81 \\
\hline \multicolumn{6}{|c|}{ PJSC"PrivatBank" } \\
\hline & 2012 & 2013 & 2014 & 2015 & 2016 \\
\hline LB0, thousand grn & 20564255 & 18325494 & 23266427 & 37697471 & 36003634 \\
\hline $\mathrm{R}$, thousand grn & 17304678 & 21109996 & 20668823 & 20565556 & 50086645 \\
\hline LB0/R & 1.19 & 0.87 & 1.13 & 1.83 & 0.72 \\
\hline
\end{tabular}

The results obtained during the first round of stress testing allow us to conclude that there is a sufficient level of liquidity buffer in JSB "Ukrgasbank" and JSC "Ukreximbank", since LB0 / R was> 1 for all reporting dates.

JSC "Oschadbank" only survived the impact of shock in 2012 and 2015, in other cases LB0 / R was $<1$. An insufficient liquidity buffer was also recorded in PJSC"PrivatBank", which in 2013 and 2016 had a buffer ratio to a liquidity deficit ratio of 0.87 and 0.72 . 
By the second stage JSB "Ukrgasbank" and JSC "Ukreximbank" pass, which endured the first round of shocks. At this stage, it is necessary to weigh the liquidity buffer of assets on the risk factors by the formula (4). Primary reserves, namely cash and cash equivalents, funds of mandatory reserves of the bank in the NBU, funds in other banks are weighted by $0 \%$, trading securities - by $10 \%$. As a result, the risk weighted risk of liquidity of assets of the JSB "Ukrgasbank" will be $0.5 \%$ in 2012, and in 2016 the bank lost $100 \%$ of the buffer. A similar situation with JSC "Ukreximbank", which will have a liquidity buffer only in 2014 at $0.5 \%$. None of the banks selected for analysis could not resist a second round of shocks.

\section{Conclusions and discussion}

The presented approach to stress testing is a tool that should be used to determine the negative impact of liquidity shocks on banks. For the purpose of the research, the model of J. V. Van den End (2008), developed in the work of Z. Komárková, A. Gershl, L. Komarek (2011) was used. Within the framework of this research, the approach was adapted to the specifics of the functioning of Ukrainian banks, in particular, the composition of primary and secondary liquidity buffers was reviewed in accordance with the financial reporting data.

The approach developed by these scholars has been tested on a group of state-owned banks (JSB "Ukrgasbank", JSC "Oschadbank", JSC "Ukreximbank" and PJSC "PrivatBank"), whose influence on the banking system of Ukraine is most significant. The results of the model showed that banks with a state share are not sufficiently protected from liquidity risk. Even with a liquidity buffer of $15-20 \%$ for state-owned banks, this was not enough to counteract the potential for liquidity stress. The impact of the first round of shocks was significant, as only JSB "Ukrgasbank" and JSC "Ukreximbank" could withstand it. The sensitivity of these banks to the influence of the second round was extremely high. After weighing the buffers on the risk factors, they lost almost $100 \%$ of the buffers, signaling their lack of quality, as these banking institutions were unable to cover further increases in the requirements of available liquidity reserves. Consequently, the main result of the study is the conclusion that even with a sufficient amount of liquidity buffers of assets with banks with a state share, their quality remains at a rather low level, the share of secondary reserves is critically low.

\section{References}

1. Basel Committee on Banking Supervision, BCBS (2013). Basel III: The Liquidity Coverage Ratio and liquidity risk monitoring tools. Available at: https://www.bis.org/publ/bcbs238.pdf.

2. Basel Committee on Banking Supervision, BCBS (2013). Liquidity stress testing: a survey of theory, empirics and current industry and supervisory practices, BIS WP /13/24. Available at: https://www.bis.org/publ/bcbs_wp24.pdf. Accessed 25 May 2018.

3. Committee of European Banking Supervisors (2009). Guidelines on Liquidity Buffers \& Survival Periods, CEBS.

4. European Systemic Risk Board, ESRB(2012). Recommendation of the European Systemic Risk Board of December 2012 on funding of credit institutions. Available at: https://www.esrb.europa.eu/pub/pdf/recommendations/2012/ESRB_2012_2.en.pdf?8de3922e86b0f4863bc6e748flfla4c0.

5. Aikman, D., Alessandri, P., Eklund, B., Gai, P., Kapadia S., Martin, E., Mora, N., Sterne G. and Willison, M. (2009). Funding Liquidity Risk in a Quantitative Model of Systemic Stability, Bank of England Working Paper No. 372.

6. Bonner, C., Van Lelyveld, I. and Zymek, R. (2013). Banks' Liquidity Buffers and the Role of Liquidity Regulation», DNB Working Paper 393.

7. Bonner, C., Van Lelyveld, I. and Zymek, R. (2013). The determinants of banks' liquidity buffers and the role of liquidity regulation, VOX CEPR's Policy Portal. Available at: https://voxeu.org/article/effect-regulation-banks-liquidity-buffers. Accessed 25 May 2018.

8. Bortnikov, H.P. and Liubich, O. O. (2016). Modeli stres-testuvannia dlia otsinky ryzykiv bankiv, Matematychne modeliuvannia v ekonomitsi, 1, 59-73.

9. Chen, I-Ju, Nguyen, Ph. Lan. (2013). The Determinants of Bank Liquidity Buffer, SSRN Electronic Journal, 10.2139/ ssrn.2313541.

10. Cifuentes, R., Shin, H.S. and Ferrucci, G. (2005). Liquidity risk and contagion, Journal of the European Economic Association, 3, 556-66. Available at: https://EconPapers.repec.org/RePEc:tpr:jeurec:v: 3:y:2005:i:2-3:p:556-566.

11. Danilova, L.I. and Savochka V.V. (2014). Stres-testuvannia v systemi ryzyk-menedzhmentu banku, Ekonomichnyi analiz, 15 (1), 244. 
12. Deléchat, C., Henao, C., Muthoora, P. and Vtyurina S. (2012). The Determinants of Banks' Liquidity Buffers in Central America, IMF, WP/12/301. Available at: https://www.imf.org/en/Publications/WP/Issues/2016/12/31/The-Determinants-of-Banks-Liquidity-Buffers-in-Central-America-40188. Accessed 25 May 2018.

13. Diuba, Yu., Murina, A. (2015). Pidkhid Natsionalnoho banku Ukrainy do stres-testuvannia ukrainskoi bankivskoi systemy, Visnyk NBU, 234, 39-52.

14. Drehmann, M., Nikolaou, K. (2009). Funding liquidity risk definition and measurement, European Central Bank Working Paper, WP/2009/03/1024. Available at: https://www.ecb.europa.eu/pub/pdf/scpwps/ecbwp1024.pdf. Accessed 25 May 2018.

15. Gauthier, C., Souiss, M. and Liu, X. (2014). Introducing Funding Liquidity Risk in a Macro Stress-Testing Framework, International Journal of Central Banking, 10(4), 105-142.

16. Gorelaya, N., Kuznetsova, K. (2017). Determinantyi bufera likvidnosti kommercheskogo banka. Korporativnyie Finansyi, 14(4), 36-53. Available at: https://cfjournal.hse.ru/article/view/6800

17. Ivasiv, I.B., Fuksman, O.Yu. (2014). Limituvannia ryzyku likvidnosti banku na osnovi stres-testuvannia, Ekonomika ta derzhava, 11, 85-89. Available at: http://nbuv.gov.ua/UJRN/ecde_2014_11_20.

18. Ivasiv, I. B., Maksymova, A.V. (2011). Makroekonomichne stres-testuvannia bankiv: sutnist, pidkhody ta osnovni etapy, Finansy, oblik i audyt, 18, 76. Available at: http://ir.kneu.edu.ua:8080/bitstream/2010/968/1/Ivasiv.pdf.

19. Komárková, Z., Geršl, A. and Komárek L. (2011). Models for Stress Testing Czech Banks' Liquidity Risk, CNB WORKING PAPER SERIES 11/2011, Czech National Bank.

20. Kuznetsov, A.R. and Pyitkin, A.N. (2015). Stress-testirovanie v bankovskom sektore: likvidnost, Izvestiya UrGEU, 3 (59). Available at: https://cyberleninka.ru/article/n/stress-testirovanie-vbankovskom-sektore-likvidnost.

21. Kyshakevych, B. Yu. (2011). Stres-testuvannia ekonomichnoho kapitalu banku na osnovi odnofaktornykh modelei, Naukovyi visnyk NLTU Ukrainy, 21(2).

22. Kyshakevych, B. Yu. and Yuzviak, O.A. (2015). Stres-testuvannia banku: pidkhody, metody, svitovyi dosvid, Naukovyi visnyk NLTU Ukrainy : zbirnyk naukovo-tekhnichnykh prats, 25.1, 277-283.

23. Maksymova, A.V. (2012). Makroekonomichne stres-testuvannia bankiv u systemi rehuliuvannia bankivskoi diialnosti, Derzhavnyi vyshchyi navchalnyi zaklad "Kryvorizkyi natsionalnyi universytet", Kryvyi Rih, 217

24. Manzhos, S. B. (2014). Stres-testuvannia bankiv: ohliad metodolohii, Fynansy, oblik, banky. 1 (20), 188195.

25. Mazun, N. H. (2010). Teoretychni osnovy stres-testuvannia yak instrumentu upravlinnia bankivskymy ryzykamy, Finansy, oblik i audyt, 16, 121-129.

26. Naumenkova, S., Mishchenko, S. (2008). Stres-testuvannia yak instrument diahnostyky finansovoi stiikosti bankiv, Visnyk NBU, 5, 18 - 23.

27. Rebryk, Yu. S., Rebryk, M. A. (2013) Metodychni aspekty stres-testuvannia likvidnosti banku z urakhuvanniam standartiv Bazelia III, Finansy Ukrainy, 4, 89-97. Available at: http://nbuv.gov.ua/UJRN/Fu_2013_4_9.

28. Sun, M. (2018). Biased Decision-Making and Liquidity Buffer in Commercial Banking, Applied Economics and Finance, Vol. 5, No. 2; March 2018. doi:10.11114/aef.v5i2.2784.

29. Travkyna, E.V. (2015). Rezultaty monytorynha ryska lykvydnosty v funktsyonyrovanyy rossyiskoho bankovskoho sektora, Fynansovaia analytyka: problemy y reshenyia, 40, 274. Available at: https://cyberleninka.ru/article/n/rezultaty-monitoringa-riska-likvidnosti-v-funktsionirovanii-rossiyskogobankovskogo-sektora.

30. Ushanov, A.E. (2016). Kratkosrochnaya bankovskaya likvidnost: novyie trebovaniya i instrumentyi upravleniya, Finansyi i kredit, 34 (706). Available at: https://cyberleninka.ru/article/n/kratkosrochnayabankovskaya-likvidnost-novye-trebovaniya-i-instrumenty-upravleniya.

31. Van den End, J. W. (2009). When Liquidity Risk Becomes a Macro-Prudential Issue: Empirical Evidence of Bank Behaviour, DNB WP No. 230, Netherlands Central Bank.

32. Vovk, V., Dmytryk, Yu. (2013). Diahnostuvannia kryzy z boku tsentralnykh bankiv: zarubizhnyi ta vitchyznianyi dosvid, Visnyk NBU, 3 (205), 20-25.

33. Wong, E. and Hui, C. (2009). A Liquidity Risk Stress-Testing Framework with Interaction between Market and Credit Risks, WP/09/06, Hong Kong Monetary Authority. Available at: https://pdfs.semanticscholar.org/5649/fb0c93dfe0b9ae335a1032cdddce8e2e5637.pdf. Accessed 25 May 2018. 
34. Zhytnyi, P.Ye. (2011). Svitova praktyka stres-testuvannia u bankakh Ukrainy. Available at: http://archive.nbuv.gov.ua/portal/soc_gum/VUABS/2011_1/30_03_08.pdf.

\section{Appendix A}

Table A.1. Components of liquidity buffers JSB "Ukrgasbank", JSC "Ukreximbank", JSC"Oschadbank", PJSC"PrivatBank" for 2012-2016, thousand hryvnias

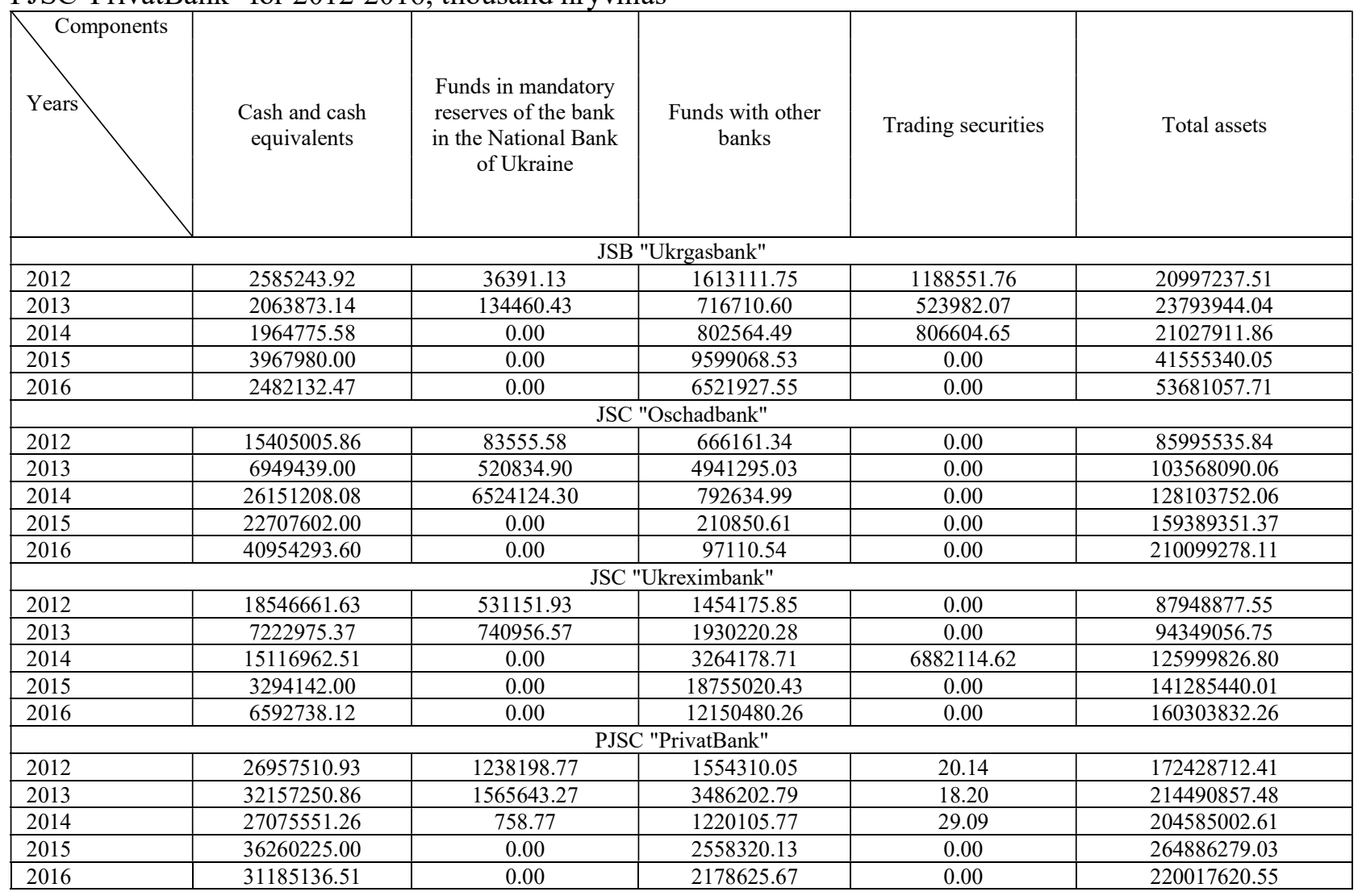

Table A.2. Data for calculating the liquidity deficit JSB "Ukrgasbank", JSC "Ukreximbank", JSC"Oschadbank", PJSC"PrivatBank" for 2012-2016

\begin{tabular}{|c|c|c|c|c|c|c|c|}
\hline Components & $\begin{array}{l}\text { L. thousand } \\
\text { hryvnias }\end{array}$ & P. $\%$ & $\begin{array}{l}\text { C. thousand } \\
\text { hryvnias }\end{array}$ & c. $\%$ & $\begin{array}{l}\text { D. thousand } \\
\text { hryvnias }\end{array}$ & r. units & $\begin{array}{l}\text { R. thousand } \\
\text { hryvnias }\end{array}$ \\
\hline \multicolumn{8}{|c|}{ JSB "Ukrgasbank" } \\
\hline 2012 & 8675120.69 & 0.54 & 1467472.25 & 26.03 & 7023617.63 & 0.26 & 2228060.66 \\
\hline 2013 & 10257720.78 & 1.18 & 1948818.95 & 18.73 & 8698687.92 & 0.23 & 2453066.75 \\
\hline 2014 & 10034858.46 & 0.98 & 49600.91 & 35.56 & 12368091.12 & 0.26 & 3280169.10 \\
\hline 2015 & 14029078.05 & 1.40 & 245140.65 & 19.20 & 27510140.15 & 0.13 & 3804788.77 \\
\hline 2016 & 20398636.97 & 1.45 & 242735.26 & 14.26 & 46180965.80 & 0.10 & 4959516.81 \\
\hline \multicolumn{8}{|c|}{ JSC "Oschadbank" } \\
\hline 2012 & 51186647.25 & 1.01 & 2205122.48 & 11.82 & 39399132.48 & 0.13 & 5901482.73 \\
\hline 2013 & 51546229.48 & 1.01 & 298898.28 & 5.94 & 46340929.31 & 0.12 & 6097740.78 \\
\hline 2014 & 69271838.30 & 1.34 & 245358.03 & 20.17 & 55368183.41 & 0.15 & 9529600.58 \\
\hline 2015 & 65687092.88 & 0.95 & 1273228.99 & 27.45 & 93437692.73 & 0.12 & 12567898.93 \\
\hline 2016 & 66194494.30 & 1.01 & 1217735.41 & 24.09 & 144419249.81 & 0.09 & 14556868.68 \\
\hline \multicolumn{8}{|c|}{ JSC "Ukreximbank" } \\
\hline 2012 & 42273618.08 & 1.05 & 191048.98 & 10.67 & 44840799.96 & 0.15 & 7011407.70 \\
\hline 2013 & 42273618.08 & 1.00 & 629029.62 & 10.00 & 42970257.50 & 0.14 & 6335655.81 \\
\hline 2014 & 52093575.46 & 1.23 & 572553.24 & 19.45 & 60125796.49 & 0.10 & 6882708.09 \\
\hline 2015 & 55038771.97 & 1.06 & 393676.58 & 28.99 & 77679021.56 & 0.09 & 7757725.74 \\
\hline 2016 & 58426563.90 & 1.06 & 528673.47 & 28.49 & 83770729.06 & 0.08 & 7483181.77 \\
\hline \multicolumn{8}{|c|}{ PJSC "PrivatBank" } \\
\hline 2012 & 113725691.54 & 0.94 & 2475773.31 & 14.64 & 106342198.18 & 0.15 & 17304678.44 \\
\hline 2013 & 142548091.67 & 1.25 & 29828737.10 & 11.05 & 133551099.98 & 0.12 & 21109996.12 \\
\hline 2014 & 161338725.51 & 1.13 & 9275042.37 & 11.44 & 141338369.21 & 0.13 & 20668822.67 \\
\hline 2015 & 177810480.90 & 1.10 & 12318997.98 & 10.54 & 178121357.31 & 0.10 & 20565555.95 \\
\hline 2016 & 54691631.45 & 0.31 & 39288224.06 & 73.18 & 180945877.43 & 0.12 & 50086644.94 \\
\hline
\end{tabular}

